Egypt. Acad. J. biolog. Sci., 5(1): 123- 129 (2013)

Email: egyptianacademic@yahoo.com

Received: $29 / 5 / 2013$
C. Physiology \& Molecular Biology

ISSN: 2090-0767

www.eajbs.eg.net

\title{
Ribosomal DNA sequences reveal a parasitic septate gregarine (Apicomplexa: Gregarinia) in the scorpion Leiurus quinquestriatus in Egypt
}

\author{
Moustafa M. H. Sarhan \\ Department of Zoology, Faculty of Science, Al-Azhar University, Assiut
}

\begin{abstract}
Ribosomal RNA genes are ubiquitously present and nucleotide sequences of many regions are relatively conserved among many organisms. Many specific PCR primers have been developed for amplification of the rDNA fragments from particular taxa. However, many authors use universal primers which can bind to conserved regions to detect protozoa pathogens that are obligate parasites of digestive tracts and body cavities in the analysed DNA sample of invertebrate animals. In this study, uncultured gregarine clones were detected by PCR and rDNA sequencing in the scorpion, Leiurus quinquestriatus (Scorpiones: Buthidae). Comparison of the amplified rDNA fragments with sequences deposited in GenBank revealed that analysed sequences corresponded to $18 \mathrm{~S}$ rDNA from the genus Gregarina ( $88 \%$ identity with Xiphocephalus ellisi). To our knowledge, this is the first record of scorpion infected with gregarines.
\end{abstract}

Keywords: rDNA, Leiurus quinquestriatus, Scorpion, Apicomplexa, gregarines

\section{INTRODUCTION}

The phylum Apicomplexa consists of unicellular protozoan parasites, infesting a wide range of Metazoa (Ellis et al. 1989). Included are numerous genera that attack humans or domesticated animals (e.g., Plasmodium, Toxoplasma, Cryptosporidium, Neospora, Theileria, Babesia, and Eimeria) (O'Donoghue 1995, Kim \& Weiss 2004). These parasites cause great suffering and economic damage, and contribute to millions of human deaths each year (Hammarton et al. 2003). Gregarines are a diverse and successful group of protozoan parasites belonging to the phylum Apicomplexa (previously called Sporozoa), order Eugregarinorida Léger, 1900. They are all parasitic and are restricted to invertebrates (Clopton 2002). They are obligatory protozoan parasites of invertebrate animals, mainly of terrestrial arthropods. Most species of gregarines are found in the host gut, although a transition from intestinal parasitism to infect the body cavity and internal organs is observed in some families (Simdyanov \& Kuvardina 2006).

Although gregarines do not attack vertebrates, they harm arthropod vectors of human and animal diseases. This is because gregarines are extremely common in both field and laboratory arthropods (Johny et al. 1999; Pushkala \& Muralirangan 1997). Gregarines are often considered to be sub-lethal or even harmless to their hosts, but in fact, they divert host nutrients to their own use, occupy space, alter host immune systems, and damage host cell walls when emerging, and thus foster microbial attack. As such, they can reduce longevity, vitality, or fecundity, or cause rapid mortality (Fukuda et al. 1997; Ball1 995). Recent studies demonstrate that gregarine infection significantly increases the effectiveness of both chemical and microbial control measures against insect pest (Lopes \& Alves 2005). 
The gregarine parasites have been reported from a variety of arthropod hosts; adults and larval stages of beetles, cockroaches, immature and adult common silverfish, adult differential grasshoppers, field cricket, naiads of the common green darner, flat-backed greenhouse millipede, nymphs and adults of the brown-winged earwig and adults of the common civil bluet damselfly (Clopton 2002). They were isolated from penaeid shrimps of Bombay (Bower et al. 1994) and Kerala (Prasadan \& Janardanan 2001). There is very little information available concerning the Gregarine pathogens of Arachnida. These pathogens were reported from mites, mainly from oribatids (Poinar \& Poinar 1998; Loo et al. 2004) and water mites (Issi \& Lipa 1968). Although few species were recorded from spiders such as Opiliones (Cokendolpher 1993), nothing is known in scorpions. Here, simple and rapid PCR and DNA sequencing of $18 \mathrm{~S}$ rDNA methods were used for the detection and identification of eukaryotic pathogens in scorpion extracted DNA. The gene coding for the small subunit of ribosomal RNA (SSU RNA) is the most intensively sequenced marker for phylogenetic studies in all groups of organisms. Newly obtained sequence data can be quickly and easily compared with all published sequences of this marker deposited in GenBank (NCBI) database. Moreover, the use of universal primers that can amplify fragments of rDNA sequences of any eukaryote species in polymerase chain reaction (PCR) makes it possible not only to amplify rDNA from the studied specimens, but also from pathogens infecting them. The amplified 18S rRNA gene fragments then individually sequenced (Valles \& Pereira 2003). The resultant sequence of the part of $18 \mathrm{~S}$ rRNA gene was compared with sequences deposited in GenBank for species identification. Results of this study revealed that, uncultured gregarine clones have been identified in the scorpion Leiurus quinquestriatus by this simple approach. This typically scorpion species inhabits the Middle East is one of the world's most dangerous scorpion species. In Africa, it occurs from Mauritania in the west to Sudan and Egypt and goes far beyond the Middle East from Saudi Arabia to Iraq, and perhaps even further east (Stockmann \& Ythier 2010), Leiurus species secrete one of the most noxious venoms among buthid scorpions in general, and are responsible for very serious human incidents and have been the subject of numerous biochemical studies (Simard \& Watt 1990; Loret \& Hammock 2001). It was proposed that each invertebrate harbors at least 1 species of gregarine; therefore, the exact number of these protozoans is hard to precisely estimate. In fact, gregarines are reported from only about 3124 invertebrate species, which is $<0.3 \%$ of the named invertebrate fauna (Levine 1988). This study aims to explore gregarine parasites in unstudied arthropod group using simple molecular techniques. This is, to our knowledge, the first record for parasitic gregarines in scorpions.

\section{MATERIALS AND METHODS Scorpion collection}

Leiurus quinquestriatus were collected and transported alive to the laboratory. They kept in separate plastic boxes until DNA extraction.

\section{DNA extraction, amplification, and sequencing}

Whole genomic DNA was extracted using DNA easy Tissue Kit (Qiagen) following the standard manufacturer's protocol. Total genomic DNA was extracted from a fragment of the scorpion's pedipalps, legs or metasoma. For PCR amplification the following primers were used in this study 18s rRNA F 5'- 
TTAAGCCATGCATGTCTAAG-3' and 18S rRNA R 'GACTACGACGGTATCTAATC-3'.

Amplification was performed on a Mini Cycler (Techgene): initial step with 3 min at $94^{\circ} \mathrm{C}$ followed by 35 steps with $30 \mathrm{sec}$ at $95{ }^{\circ} \mathrm{C}, 30 \mathrm{sec}$ at $52{ }^{\circ} \mathrm{C}$ and 3 min at $72{ }^{\circ} \mathrm{C}$, and with final elongation $10 \mathrm{~min}$ at $72{ }^{\circ} \mathrm{C}$. Reaction mix contained $5 \mu \mathrm{l}$ of DNA template, $12.5 \mu \mathrm{l}$ of GoTaq Green Master mix (Promega), 0.5 $\mu \mathrm{l}$ of primer $\mathrm{F}, 0.5 \mu \mathrm{l}$ of primer $\mathrm{R}(10$ pmoles) and the rest is nuclease free water until it reaches a total volume of $25 \mu 1$. Amplification products were separated by electrophoresis on $1.5 \%$ agarose gel, purified using QIAquick Gel Extractinion Kit (Qiagen), and sequenced on genetic analyser ABI Prism 3500 (Applied Biosystems) using the BigDye Terminator v3.1 chemistry of the same manufacturer. Chromatograms and sequences were analyzed and edited using BioEdit program $\AA$. A BLASTn search was used to infer the taxonomic affiliation of these sequences. The gregarine-like sequences were compared with corresponding sequences from the GenBank database. For phylogenetic analysis 33 sequences in total were used, including: The gregarine-like sequences from this study, 28 sequences designated as Gregarinia and 4 other apicomplexan species (a close outgroup). For the 18S rRNA gene, Maximum Likelihood tree was constructed with bootstrap analysis employed 1000 replicates. The TN93 (Tamura-Nie) + G (gamma) model of nucleotide substitution was determined as the most appropriate model according to Bayesian Information Criterion (BIC) and Akaike Information Criterion (AIC) (Nei M. and Kumar S. 2000). The analysis involved 4 nucleotide sequences. Codon positions included were $1 \mathrm{st}+2 \mathrm{nd}+3 \mathrm{rd}+$ Noncoding. All positions containing gaps and missing data were eliminated. There were a total of 919 positions in the final dataset. Genetic distances were created in MEGA5 software (http://www.megasoftware.net).

\section{RESULTS}

Amplification of the rDNA fragment with the universal primers from the genomic DNA isolated from $L$. quinquestriatus revealed specific strong PCR product (Fig. 1). Comparison of the nucleotide sequence of amplicons with sequences deposited in GenBank showed that the $900 \mathrm{~kb}$ fragment was most similar to the Xiphocephalus ellisi $18 \mathrm{~S}$ ribosomal RNA gene (Acc. FJ459762) revealing 794/903(88\%) identity; Stylocephalus giganteus 18S ribosomal RNA gene [Acc. FJ459761, 792/902 (88\%) identity]; Xiphocephalus triplogemmatus $18 \mathrm{~S}$ ribosomal RNA gene [Acc. FJ459763, 751/861 (87\%) identity].

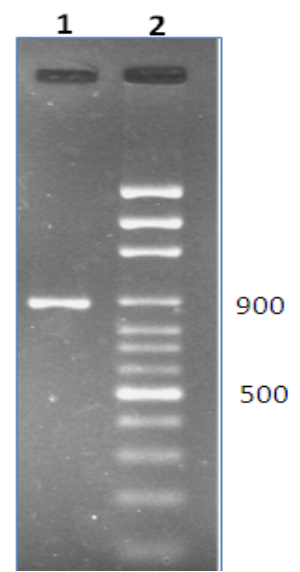

Fig. 1: PCR products ( $~ 900 \mathrm{bp}$ fragment) of $18 \mathrm{~S}$ rRNA gene amplified by universal primers pair from Egyptian L. quinquestriatus (1), and 100 bp DNA Ladder Marker (2). 
To reveal the phylogenetic position of the isolated gregarine-like sequences, corresponding $18 \mathrm{~S}$ rRNA sequences that have been annotated to Gregarinia in the GenBank database were used as shown in Clopton (2002). The ML analysis proved that the isolate was deeply nested in frame of the clades in Gregarinia tree (Fig. 2). Garegrine that is found in scorpion is closely related and belong most probably to Stylocephlidae group escpecially Xiphocephalus ellisi.

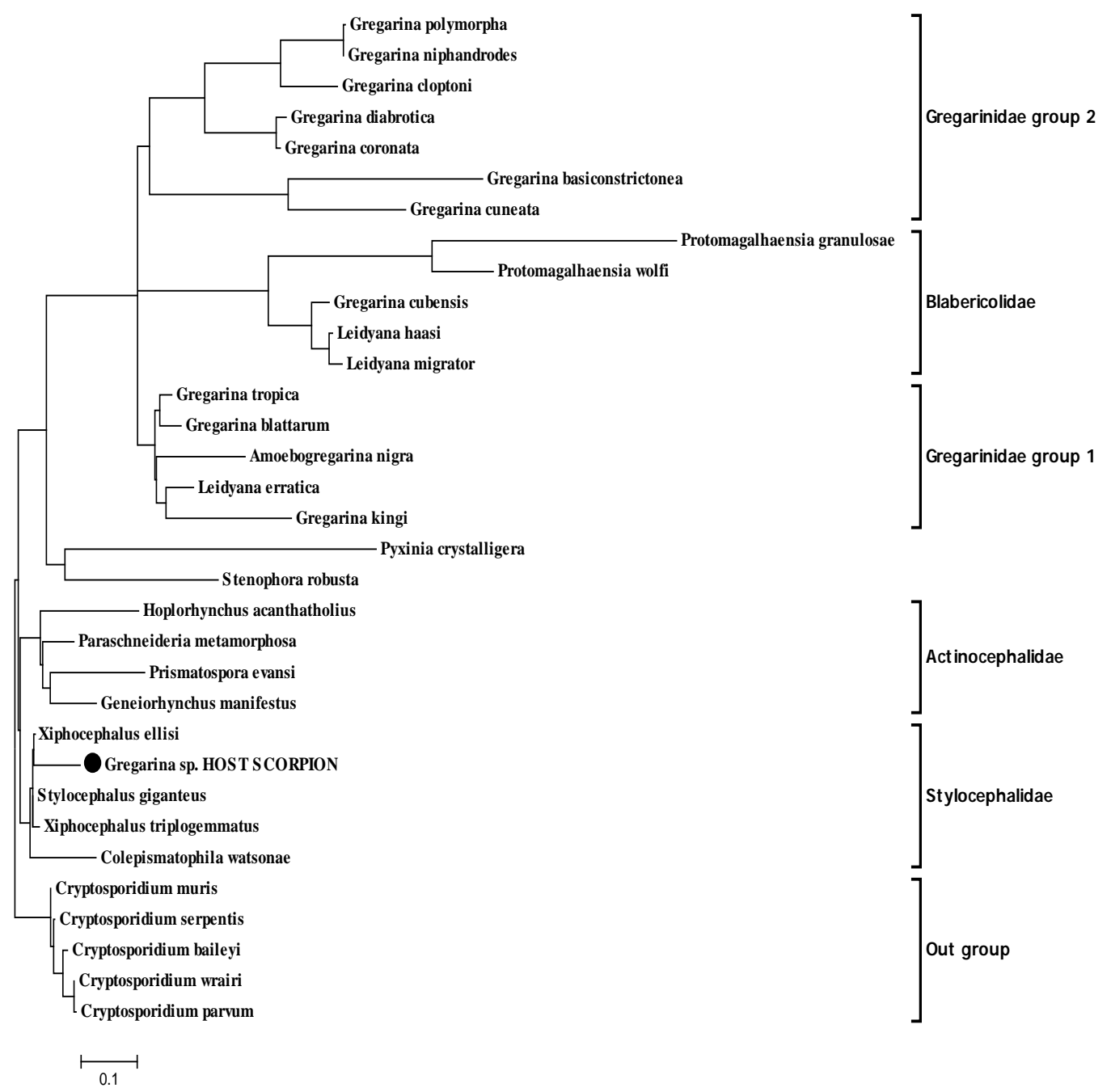

Fig. 2: Phylogenetic position of the isolated gregarine-like sequences. Maximum likelihood tree inferred from nucleotide sequences of $18 \mathrm{~S}$ rRNA gene fragments of the isolate from scorpion (black circle), and corresponding sequences from the GenBank database annotated to Gregarinia. Representatives of other Apicomplexa were used as outgroups.

\section{DISCUSSION}

Gregarines are protozoa belonging to the phylum Apicomplexa that live in digestive tracts, Malpighian tubules, fat tissue, hemolymph, or reproductive organs of marine and terrestrial invertebrates (Chen et al. 1997; Field \&
Michiels 2006: Valigurová \& Koudela 2006).

The current genetic analysis showed that the scorpion gregarine is only distantly closely related to Gregarina. The phylogeny constructed by rRNA gene sequences revealed that the 
found gregarine sequence is phylogenetically distinct from all available Gregarina species. Actually, molecular phylogenetic approaches are very useful for the systematics of gregarine parasites because their life histories involve several developmental stages (e.g., cysts, sprorozoites, and trophozoites) that complicate species identification based on morphology alone (Leander 2008; Rueckert et al. 2011; Wakeman \& Leander 2012). On contrary, Clopton 2012 argued strongly against the massive use of molecular phylogenetic data for describing gregarine species in favor of a set of ideological rules based on detailed analyses of morphometric data.

The finding of a gregarine infection in the scorpions may shed light on further pest control regimes of this dangerous species. Recent studies demonstrate that gregarine infection significantly increases the effectiveness of both chemical and microbial control measures against insect pest (Lopes \& Alves 2005). Hence, controlling an arthropod vector may hinge on the presence of gregarines.

Finally, molecular methods including DNA isolation, PCR and sequencing seem to be a promising approach to study protozoan diversity by providing a rapid and easy screening of host organisms for which traditional microscopic techniques could be ineffective.

\section{ACKNOWLDGEMENT}

The author is grateful to Prof. Dr. Mohamed Moussa Ibrahim, Professor of parasitology, Zoology Dept., Faculty of Science, Suez Canal University, Ismailia, Egypt, for reviewing the manuscript.

\section{REFERENCES}

Ball, S., Cunningham, A.A., Clarke, D. \& Daszak, P. 1995: Septate gregarines associated with a disease of the hissing cockroach
Gromphadorhina portentosa. J. Invertebr. Pathol., 65:311-312.

Bower, S.M., McGladdery, S.E. \& Price, I.M. 1994: Synopsis of infectious diseases and parasites of commercially exploited shellfish. Ann Rev Fish Dis 4:1-199

Chen, W.J., Wu, S.T., Chow, C.Y. \& Yang, C.H. 1997: Sporogonic development of the gregarine Ascogregarina taiwanensis (Lien and Levine) (Apicomplexa: Lecudinidae) in its natural host Aedes albopictus (Skuse) (Diptera: Culicidae). J. Eukaryot. Microbiol., 44: 326-331.

Clopton, R.E. 2002: Phylum Apicomplexa Levine, 1970: Order Eugregarinorida Lé ger, 1900. In: Lee JJ, Leedale G, Patterson D, Bradbury PC (eds) Illustrated guide to the protozoa, 2nd ed. Society of Protozoologists, Lawrence, Kansas, pp 205-288.

Clopton, R. E. 2012. Synoptic revision of Blabericola

(Apicomplexa:Eugregarinida:

Blabericolidae) parasitizing blaberid cockroaches

(Dictyoptera: Blaberidae), with comments on delineating gregarine species boundaries. J. Parasitol., 98:572-583.

Cokendolpher, J. C. 1993: Pathogens and parasites of Opiliones (Arthropoda: Arachnida). J. Arachn., 21: 120 - 146

Ellis, J., Morrison, D.A., Jeffries, A.C. 1989: The phylum Apicomplexa: an update on the molecular phylogeny. In Evolutionary Relationships Among Protozoa Edited by: Coombs G, Vickerman K, Sleigh M, Warren A. Kluwer Academic Publishers, Boston; 255-274.

Field, S.G. \& Michiels, N.K. 2006: Acephaline gregarine parasites (Monocystis sp.) are not 
transmitted sexually among their lumbricid earthworm hosts. J. Parasitol., 92: 292-297.

Fukuda, T., Willis, O.R \&\& Barnard, D.R. 1997: Parasites of the Asian tiger mosquito and other container-inhabiting mosquitoes (Diptera: Culicidae) in northcentral Florida. J. Med. Entomol., 34:226-233.

Hammarton, T.C., Mottram, J.C. \& Doerig, C. 2003: The cell cycle of parasitic protozoa: potential for chemotherapeutic exploitation. Prog Cell Cycle Res., 5:91-101.

Issi, I.V. \& Lipa, J. 1968: Gurleya sokolovi sp.n, a microsporidian parasite of the water mite Limnocheres aquatica (Linnaeus) (Acarina: Hydrachnellae), and a note on a gregarine infection in the same mite. J. Invertebr. Pathol., 10: 165 - 175

Johny S., Muthukumaravel, K., Raghu, S., Muralirangan, M.C. \& Sanjayan, K.P. 1999: Geographical distribution of cephaline gregarines (Apicomplexa :Protozoa) in relation to grasshoppers (Orthoptera: Acrididae) in Tamil Nadu, India. Int. J. Ecol. Environ. Sc.i, 25:201-207.

Kim, K. \& Weiss, L.M. 2004: Toxoplasma gondii: the model apicomplexan. Int. J. Parasitol., 34:423-432.

Leander, B. S. (2008): Marine gregarines - evolutionary prelude to the apicomplexan radiation? Trends Parasitol., 24:60-67.

Levine, N.D. 1988: The protozoan phylum Apicomplexa. I and II. Boca Raton, FL: CRC Press.

Loo, A. H. B., Ong, T. C., Jethanand, H. , Choy, M. S., Barta, J. R. \& Chew, F. T. 2004: The detection of an Apicomplexan (order Neogregarinorida) pathogen in the dust mite Acarus siro - a novel hostpathogen relationship: Implication to dust mite life cycle and allergen extract purity. Program and Abstracts of papers presented during Scientific Sessions - AAAAI 60th Annual Meeting. J. Allergy Clin. Immunol., 113 (2): 139

Lopes, R.B.G. \& Alves S.B. 2005: Effect of Gregarina sp. parasitism on the susceptibility of Blattella germanica to some control agents. J. Invertebr. Pathol., 88:261-264.

LORET, E. \& B. Hammock. 2001: Structure and neurotoxicity of scorpion toxins. Pp. 204-233 in Brownell, P. H. \& Polis G. A. (eds). Scorpion Biology and Research. Oxford: Oxford University Press.

O'Donoghue, P.J. 1995: Cryptosporidium and cryptosporidiosis in man and animals. Int. J. Parasitol., 25:139195.

Nei, M. and Kumar, S. 2000: Molecular Evolution and Phylogenetics. Oxford University Press, New York (333 pp).

Poinar, G. Jr \& Poinar, R. 1998: Parasites and pathogens of mites. Annu. Rev. Entomol., 43: 449 - 469

Prasadan, P.K. \& Janardanan, P.K. 2001: Three new species of Gregarines (Apicomplexa: Sporozoea: Porosporidae) in the Estuarine Crabs from Kerala, India. Acta. Protozool., 40:303-309

Pushkala, K. \& Muralirangan, M.C. 1997: Impact of Gregarina subramanii, a new gregarine species on the biology of the grasshopper;Eyprepocnemis alacris alacris (Serville). The Entomologist ,116:130-141.

Rueckert, S., Simdyanov, T.G., Aleoshin, V.V. \& Leander, BS. 2011: Identification of a divergent environmental DNAsequence clade using the phylogeny of gregarine 
(Apicomplexa) from crustacean hosts. PLoS ONE, 6:e18163.

Simard, J.M. \& Watt, D.D.1990: Venoms and toxins. In: The biology of scorpions (Polis GA, ed). Stanford Ca, USA: Stanford University Press, pp 414-44

Simdyanov, T. G. \& Kuvardina, O. N. 2006: Fine structure and putative feeding mechanism of the archigregarine Selenidium orientale (Apicomplexa: Gregarinomorpha). Eur. J. Protistol., 43(1): 17 - 25

Stockmann, R. \& Ythier, E. 2010: Scorpions of the world. Verrièresle-Buisson: NAP Editions.; 565p.

Valigurová, A. \& Koudela, B. 2006: Ultrastructural study of developmental stages of Mattesia dispora (Neogregarinorida: Lipotrophidae), a parasite of the flour moth Ephestia kuehniella (Lepidoptera). Eur. J. Protistol., 42: 313-323.

Valles, S. M. \& Pereira, R. M. 2003: Use of ribosomal DNA sequence data to characterize and detect a neogregarine pathogen of Solenopsis invicta (Hymenoptera: Formicidae). J. Invertebr. Pathol., 84: $114-118$

Wakeman, K. C. \& Leander, B. S. 2012: Molecular phylogeny of pacific archigregarines (Apicomplexa), including descriptions of Veloxidium leptosynaptae n. gen., n. sp., from the sea cucumber Leptosynapta clarki (Echinodermata), and two new species of Selenidium. J. Eukaryot. Microbiol., 59:232-45. 